\title{
Children's Rights Conflict with the Law in the Time of the COVID-19 Pandemic
}

\author{
Riduansyah, Risdalina, Sriono*, Indra Kumalasari M and Muhammad Yusuf Siregar
}

\author{
Faculty of Law, Labuhanbatu University, North Sumatera, Indonesia
}

\begin{abstract}
Children are individuals who are less than 18 years old. Children both in the constitution of the Republic of Indonesia and internationally have the right to be protected. This scientific work aims to analyze the rights of children who are in conflict with the law during the covid 19 pandemic, do children who are in conflict with the law during the covid 19 pandemic get special rights? The method used to obtain data in this scientific work is using the empirical juridical method with primary data obtained directly. Based on the results of the analysis conducted, the rights of children who are in conflict with the law during the COVID-19 pandemic in Indonesia get special rights or get special treatment. The rights of children given are the right to survival (survival rights), the right to grow and develop (development rights), the right to obtain protection (protection rights), the right to participate (participation rights). Giving health rights to children in conflict, and resolving legal conflicts by prioritizing the diversion process, namely the transfer of the settlement of children's cases from the criminal justice process to processes outside criminal justice. There are obstacles or obstacles in handling children who are in conflict with the law, namely in general the detention rooms for children in Indonesia are not adequate, even some areas do not have special detention rooms for children and special investigators for children. and resolve legal conflicts by prioritizing the diversion process, namely the transfer of the settlement of children's cases from the criminal justice process to processes outside of criminal justice. There are obstacles or obstacles in handling children who are in conflict with the law, namely in general the detention rooms for children in Indonesia are not adequate, even some areas do not have special detention rooms for children and special investigators for children. and resolve legal conflicts by prioritizing the diversion process, namely the transfer of the settlement of children's cases from the criminal justice process to processes outside of criminal justice. There are obstacles or obstacles in handling children who are in conflict with the law, namely in general the detention rooms for children in Indonesia are not adequate, even some areas do not have special detention rooms for children and special investigators for children.
\end{abstract}

Keywords: Children's Rights, Legal Conflicts, the Covid-19 Pandemic.

\section{INTRODUCTION}

Children are an inseparable part of the continuity of human life and the sustainability of a nation and state. Constitution 1945 Article 28 B paragraph (2) states that the State guarantees that every child has the right to survive, grow and develop as well as the right to protection from violence and discrimination. Therefore, we all always strive so that children do not become victims of violence, and children fall into committing evil or other dishonorable deeds (Widayanti, N., and Anoraga, P., 2007). Children have inherent rights, so they must be guarded not only by parents but also by the state (Sagala, E. 2018). In fact, children are often involved in crimes caused by many factors.

Children who have legal problems have many dynamics and challenges in terms of the constitution and human rights, but crimes involving children have their own way of resolving (Y. Indarsih, 2020). Indonesia has signed and ratified the convention on the rights of the child, especially in the field of children in conflict with the law. But in its implementation until now it has not been maximized (Sharyn Graham Davies and Jazz Robson, 2016).

*Address correspondence to this author at the Faculty of Law, Labuhanbatu University, North Sumatera, Indonesia; Tel: (0624) 21901;

E-mail: sriono.mkn@gmail.com
Referring to data from the Indonesian Child Protection Commission (KPAl), crimes committed by children have increased in the last decade. The number of children who become criminals is increasing. This drastic increase was seen in a number of cases handled by the police. From 2011 to the end of 2018, KPAI reported that at least 11,116 children were involved in criminal cases. Those who are involved in the law include being caught in motorcycle gang cases, theft, violent theft, to murder. Lthe Correctional Institution is also the second home for those who still need parental guidance (Yusuf, Y., 2019).

The Covid-19 pandemic that lasted more than a year changing the situation and condition of children in Indonesia, especially with regard to legal issues. Criminal acts involving children dealing with the law increased from 2019 compared to 2020. During the Covid-19 pandemic, cases of children dealing with the law $(\mathrm{ABH})$ increased in several regions in Indonesia. Children's boredom during online or online learning, lack of parental supervision are considered as factors causing the increase in cases of children being involved with the law. There are children who are bored at home, then they gather with their friends and commit criminal acts such as motorbike gangs, there are children who are subject to theft because they are ordered by an older person, but most of the crimes 
committed by children are immoral (Farasonalia, R., 2021).

In accordance with the Convention on the Rights of the Child which has been ratified by Indonesia through Presidential Decree No. 36 of 1990, therefore Indonesia should have made a deep commitment to protecting children's rights as a whole. In addition, Indonesia also has Law Number 23 of 2002 concerning Child Protection as an effort to provide efforts to protect children's rights such as in the fields of education, health, religion, and social, including the rights of children in conflict with the law. Children who are in conflict with the law are included in the criteria given Special Protection as stated in Article 59 of Law Number 23 Year 2002. This is the responsibility of the government and society.

Child development refers to how the child changes and grows during his childhood. In it there are various aspects ranging from social, emotional, to cognitive. Based on the age range of the child, there are several periods as a progressive period, namely between the ages of 0 years to 20 years, in which during this period humans or what is meant by children in this paper must go through periods of crisis 2 times, which is estimated by the Developmental psychologist at 2 to 4 years of age and at 12 to 18 years of age (Meliala, A. Qirom Syamsudin and E. Sumaryono., 2005).

Children have rights, including the right to care, the right to health, the right to protection, and the right to education. The state needs to ensure that the human rights of every child deprived of their liberty are truly respected, protected and fulfilled in response to the Covid-19 pandemic. This includes providing adequate care and protection from hazards, including by taking concrete steps to reduce overcrowding orovercrowdingin child detention facilities and ensuring that every child is placed in a safe environment, whether in a non-custody, family, or community residence. This also means that all decisions and actions concerning children must be based on the principles of the best interests of the child, as well as children's rights to live, survive and develop, and to be heard.

In the act of handling child perpetrators of this crime, of course, it cannot be separated from the role of the state as the party involved authorized to handle criminal cases that are included in public law. The state is obliged to intervene in the handling of children who are perpetrators of this crime, considering that children are a potential source of a large State and the actions of these children fall within the scope of public law. There needs to be protection for children who are caught in legal cases so that they can return to being good.

Concrete efforts from all implementing agencies related to efforts to deal with children in conflict with the law have been made but have not shown significant results in providing support for the protection of children's rights in situations of imprisonment. Children who experience cases with the law, in the judicial process are still needed and processed in the laws and regulations that are currently in effect and have not implemented the concept of Diversion andRestorative Justice (Restorative justice), namely providing protection for the best of the child.

The police, as law enforcement officers, have a legally valid position to limit the rights of a person in society, especially those who are suspected of committing a criminal act, but nevertheless there are factors that must be considered in terms of limiting a person's rights, both to adult and perpetrators of criminal acts who are still classified as children. In responding to the provisions of child crime or child delinquency, law enforcement officials in the State, especially the police, have not fully implemented what has been stipulated or outlined in the United Nations (UN) Convention on the Rights of the Child, Law No. 35 of 2014 concerning Child Protection andLaw No. 11 of 2012 concerning Juvenile Justice, in treating children as suspects, not a few children who are involved in a criminal act receive improper treatment.

As a sample in reviewing and analyzing the rights of children in conflict with the law during the covid-19 pandemic in this scientific work, the Labuhanbatu resort police. The Labuhanbatu Police as a police institution at the district level has the duty and authority to handle criminal matters including crimes involving children as perpetrators during the Covid-19 pandemic. The Labuhanbatu Police are demanded for professionalism, especially in handling cases involving children as perpetrators of criminal acts during the Covid-19 pandemic, especially those concerning children's rights, application of laws and application of articles and criminal acts they have committed. The Labuhanbatu Police in carrying out their duties as law enforcers encountered obstacles in handling cases of criminal acts such as the absence of special investigators for children. The method used to complete this scientific work is done by using the 
empirical juridical method. The main data used is the results obtained directly, namely the Labuhanbatu resort police

\section{CHILDREN IN CONFLICT WITH THE LAW}

A child is defined as a man or girl who is not yet mature or has not yet gone through puberty. Whereas the dimension of conflict with the law means that there are acts of children that are contrary to the provisions of the applicable and legal laws in Indonesia, so that in this context it can be defined that children in conflict with the law mean children who are not yet adults. according to the law and perform actions that are contrary to the provisions of the applicable law and law. Generally, children in conflict with the law are defined as children who are suspected, charged or found guilty of violating legal provisions, or a child who is suspected of having committed or who has been found to have committed an offense of law (Farid, Mohammad., 2016).

In positive law in Indonesia, children are defined as immature people (minderjarig / person under age), people who are minors / underage conditions (minderjarigheid / inferiority) or commonly referred to as children who are under the supervision of a guardian (minderjarig under voordij). The definition of the child itself when viewed further in terms of chronological age according to the law can vary depending on the place, time and for what purposes, this will also affect the limits used to determine the child's age. We can see the difference in understanding of the child in each of the laws and regulations that exist at this time. For example, the definition of a child according to Law Number 4 of 1979 concerning Child Welfare is someone who has not reached the age of 21 years and has never been married (Abdussalam, 2007).

Law Number 39 of 1999 concerning Human Rights defines the definition of a child as every human being under the age of 18 (eighteen) and unmarried, including a child who is still womb if it is in his interest.

It is too extreme if a crime committed by children is called a crime, because basically children have an unstable mental condition, the process of psychological stability results in a critical, aggressive and exhibits behavior that tends to act to disrupt public order. This cannot be said to be a crime, but rather delinquency that is caused by an imbalanced psychological condition and the perpetrator is not aware and understands the action he has committed.
Juvenile Deliquency namely behavior / dursila, or crimes / delinquency in children, is a symptom of social illness (pathology) in children caused by a form of social neglect so that they develop a form of neglect of deviant behavior. Meanwhile, according to Atmasasmita, Juvenile Deliquency is: every act or behavior of a child under 18 years of age and unmarried which is a violation of applicable legal norms and can endanger the personal development of the child concerned (Atmasasmita, Romli., 2009).

\section{RIGHTS OF CHILDREN IN CONFLICT WITH THE LAW}

Children's rights are one of the most important things that should not be forgotten, because it is a form of approach to protecting children from legal problems. The child's right has the same position as other human beings or other legal subjects. Children's rights are something that the child has who is equipped with strength (macht) given by the legal system / legal order to the child concerned. The handling of children in conflict with the law must pay attention to the perspective of procedural justice (Beneitez. Maria Jose Bernuz, Dumortier. Els., 2018).

In particular, the protection and rights of children in conflict with the law are contained in Article 66 paragraphs (1), (2), (3), (4), (5), (6) and (7) Law Number 39 of 1999. About Human RightsAge Article 66 paragraph (1) reads "every child has the right not to be subjected to torture, torture, or punishment that is inhumane". Paragraph (2) reads "the death penalty or life sentence cannot be imposed for the perpetrator of a criminal offense who is still a child". Paragraph (3) reads "every child has the right not to be illegally deprived of his / her freedom". Paragraph (4) reads "the arrest, detention or imprisonment of children may only be carried out in accordance with the applicable law and can only be carried out as a last resort". In paragraph (5) it reads "every child who is deprived of his freedom has the right to receive humane treatment and with due observance of personal development needs according to his age and must be separated from adults, except for his own sake". Paragraph (6) reads "every child who is deprived of his / her freedom has the right to obtain legal aid or other assistance effectively in every stage of the legal remedy in effect". Paragraph (7) reads "every child who is deprived of his freedom has the right to defend himself and receive justice in front of an objective and impartial Juvenile Court in a trial that is closed to the public" (Wadong, Maulana Hasan., 2012). 
United Nations Convention on the Rights of the Child or Convention On The Rights Of The Child (CRC) applies to all children and in all contexts, including in emergency situations. Every day around the world, hundreds of thousands of children are deprived of their liberty in detention facilities. Although anyone can catch the disease caused by the coronavirus (COVID-19), children who are deprived of their liberty in detention facilities, including those detained with their parents or carers, those who are in immigration detention and those detained for reasons of national security, face a higher risk of contracting and transmitting the disease. The measures implemented to control the spread of the virus and the social impacts of such measures are also likely to have a negative impact on the quality of life and healthy development of children, including adequate care in detention, and family and community support.

Under Article 24 of the CRC, children are entitled to the highest attainable standard of health. Children who are deprived of their liberty are more susceptible to infection with Covid-19 due to the limitations of their living conditions. Deprivation of liberty complicates the application of self-isolation or physical restriction, especially in overcrowded and unsanitary detention facilities, where access to water, sanitation and basic hygiene is restricted for security or infrastructure reasons. Children deprived of their liberty have similar demographic characteristics, are in worse health than the rest of the population in general, are likely to have or experience psychosocial, physical and mental health problems that are exacerbated by the fact that they are placed in detention without adequate health services. quality even before it became an emergency.

Detention facilities not only place children at high risk of contracting the virus, but also staff working in detention facilities (police officers, detention officers, carers, social workers, health workers, etc.), their families and local residents. Staff may not be provided with personal protective equipment. Staff may also experience fear and face stigma, particularly if it is spreadingthe outbreak occurred from inside the detention facility. In various countries, Covid-19 has begun to emerge in prisons, detention centers and immigration detention, as well as other places where children are deprived of their liberty. In response to this phenomenon, many countries are now taking precautionary measures to reduce the number of children deprived of their liberty.

In addition, public health prevention and control measures in detention facilities can increase children's vulnerability to a variety of previously high risks of violence, including gender-based violence. In many cases, detention facilities are located far from the child's family, home and home environment and routine communication is often limited. This contributes to greater fear and uncertainty, which further affects the health and well-being (including mental and psychosocial well-being) of children and their families. Children may also face stigma if an outbreak breaks out in detention facilities, potentially making them fall further behind. Besides that, staff falling ill result in an insufficient staff size to care for and protect children deprived of their liberty. Lack of supervision and care has the potential to increase children's vulnerability, including vulnerability to violence, abuse and neglect, and increase the likelihood that they will be confined in smaller spaces to make them easier to control or supervise.

In some countries, steps to stop the spread of Covid-19 have actually increased the number of children deprived of their liberty. In addition, the release of detainees remains limited even though there is an amnesty or an order to release prisoners regularlygeneral purpose aimed at reducing the density of detention facilities. Such measures include closure of courts, postponement of criminal or administrative hearings, restrictions on freedom of movement, restrictions on access to lawyers or families for deprived children of their liberty, closing borders, or expanding the application of pre-transfer detention instead of termination of deportation. and the release of children into non-custodial alternative care.

Steps that key actors in the justice sector can take to prevent disenfranchisement and ensure children are released from detention during the Covid-19 pandemic. Police officers, detainees, immigration, border guards, and other law enforcement officers can:

1. Removing fines, reducing charges, arrest and detention of children, including those related to countermeasures such as violations of curfews / restrictions on movement

2. Apply child friendly and gender sensitive techniques in interacting with children

3. Remove / divert children from the formal justice system as early as possible after first contact, and at any stage of the judicial process

4. Review probation and supervision requirements for children (especially in-person visits) to allow 
physical distancing wherever possible (for example, by utilizing technology for meetings or surveillance activities)

5. In the effort to enforce immigration, screen and immediately refer all children and families of migrants, asylum seekers and refugees to appropriate protection facilities, protection officers and child care.

In the event that the criminal act is committed by a child before the age of 18 (eighteen) and is submitted to a court session after the child in question exceeds the age limit of 18 (eighteen) years, but has not reached the age of 21 (twenty one) years, the child is still filed. to the Son trial.

The categories of basic children's rights according to the 1989 Convention on the Rights of the Child include:

1. Survival rights, namely the right to enjoy survival, including the right to receive protection and attention both before and after birth.

2. Development rights, namely the right to fully develop one's potential, including the right to play, the right to education, peace and rest and to participate in activities.

3. Protection rights, namely protection from anything that can interfere with its development, both physiologically, psychologically and socially. And this applies to all children without distinction.

4. The right to participate (participation rights), namely the opportunity to participate in family, culture and social life with reference to freedom of expression, expressing opinions, access to information and the need to develop children's ideas.

Arif Gosita (2017), argue that there are several children's rights that need to be considered and fought for together, namely:

1. Before the trial: a. The right to be treated as unproven; b. The right to receive protection against actions that are detrimental, causing mental, physical, social suffering from anyone (threats, persecution, methods and places of detention for example); c. The right to get a companion, advisor in order to prepare themselves to participate in the upcoming trial with the Prodeo; $d$. The right to obtain facilities participates in facilitating the examination of himself (transport, counseling from the authorities).

2. During the trial: a. Get an explanation of the procedure for the trial and the case; $b$. The right to get a companion, advisor during the trial; c. The right to participate in facilitating the trial of himself (transport, health care); $d$. which is detrimental, causing mental, physical, social suffering (various kinds of threats, persecution, methods and places of detention for example). e. The right to express an opinion. f. The right to request compensation for treatment that caused suffering, because of being arrested, detained, prosecuted or tried without reasons based on law or because of mistakes regarding the person or legal entity which is applied in a manner regulated in the Criminal Procedure Code (article 1 paragraph 22) $\mathrm{g}$. The right to receive positive coaching / punishment treatment, who is still developing himself as a whole human. $h$. The right to a closed trial is in his interest.

3. After the trial: a. The right to receive humane guidance or punishment in accordance with Pancasila, the 1945 Constitution and the idea of correctionalism. b. The right to get protection against actions that are harmful, causing mental, physical, social suffering from anyone (various kinds of threats, persecution, murder for example). c. The right to stay in touch with his parents, his family (Dellyana, Shanty., 2012).

\section{THE PROCESS OF INVESTIGATING CHILDREN AS PERPETRATORS OF A CRIME AT THE LABUHANBATU POLICE}

Police as law enforcers need a fixed procedure to ensure objectivity and efficiency in law enforcement (Boris V. Makogon et al., 2020). Labuhanbatu Police in conducting investigations of minors involved or involved as perpetrators of criminal acts must be professional and must not deviate from the rules made by the government. In order to investigate a child as the perpetrator of a crime, in this case the investigator needs to take appropriate steps before carrying out an investigation.

The police (investigator) before carrying out an investigation into a criminal act, it is necessary to carry out an investigation. The position of the investigator according to article 1 point 1 of the Criminal Procedure 
Code states that the investigator is a police official of the Republic of Indonesia or certain civil servants who are given special authority by law to carry out investigations. This Criminal Procedure Code provides the main task for investigators which must be carried out to handle criminal acts that are accepted, whether caught in the act, complaints, and reports. In addition, the Criminal Procedure Code also provides investigators with the following powers:

\section{Arrest \\ 2. Detention \\ 3. Conduct an examination at the scene of the Case}

4. Carry out a search

5. Conducting suspect examinations and interrogations

6. Making an Audit Minutes (BAP)

7. Make a foreclosure

\section{Delegate the case}

Broadly speaking, the investigator's duties consist of carrying out field operations and legal administrative duties. In carrying out investigations of children as perpetrators of crimes, an investigator must understand the Criminal Procedure Code for Children as stipulated in Law No. 11 of 2012 concerning Juvenile Justice, because here the task of an investigator will be faced with matters relating to the enforcement of children's rights.

As for the substance regulated in the Child Criminal Justice System Law (SPPA), among others, the placement of children who undergo judicial processes can be placed in the Special Development Institution for Children (LPKA). The most basic substance in this Law is strict regulation regarding Restorative Justice and Diversion which is intended to avoid and keep children away from the judicial process so as to avoid stigmatization of children who are in conflict with the law and it is hoped that children can return to the social environment properly. This includes, among other things, what is mentioned in the section on the General Explanation of the Law on the Juvenile Criminal Justice System. Restorative Justice is a process of diversification, that is, all parties involved in a certain criminal act jointly solve the problem and create an obligation to make things better by involving victims, children and the community in seeking solutions to improve, reconcile, and reassure hearts that are not based on retaliation. Diversion is the transfer of settlement of juvenile cases from criminal justice processes to processes outside of criminal justice.

Diversion programs can take many forms restorative justiceif encouraging children to take responsibility for their actions; provide opportunities for children to make up for their mistakes by doing good for the victim; provide opportunities for the victim to participate in the process; provide opportunities for children to be able to maintain relationships with family; provide opportunities for reconciliation and healing in communities that have been harmed by criminal acts; The police, public prosecutors or other bodies dealing with juvenile cases will be empowered to decide such cases, at their discretion, without the use of formal preliminary hearings, according to the criteria established for that purpose in the legal system. respectively and also in accordance with the principles contained in these regulations.

The forms of diversion include non-intervention; informal warning; formal warning; replacing mistakes with kindness / restitution; society service; involvement in skills programs; individual plans between police, children and families; plans decided by traditional meeting plans based on the results of family group meetings; Any transfer involving referral to community services or other services will require the consent of the youth, or the guardian's parents, provided the decision to refer to the case is subject to review by the competent authority of the application.

Diversion has basic principles, which can be referred to as follows:

1. Children should not be forced to admit that they have done certain actions;

2. The Diversion Program is only used with children who admit that they have done something wrong. But there should be no coercion;

3. Imprisonment cannot be part of the Diversion. Because the mechanism and structure of Diversion does not allow the deprivation of liberty in all forms;

4. There is the possibility of submission to court (the case must be transferred back to the formal justice system if no solution can be taken); 
5. There is a right to obtain a trial or a review. The child must still be able to defend his right to obtain a trial or a review;

6. There should be no discrimination.

So that in its current development, not all cases of children who face the law at the Labuhanbatu Police must be resolved through legal channels but can be done Diversion (diversion). What is meant by Diversion is the transfer of handling of cases of children who are suspected of having committed a criminal offense from the formal process with or without conditions. Diversion is carried out in cases that are light in nature and carried out by involving parents / guardians, schools, communities, non-governmental organizations, prisons and the Social Service. Diversion is a form of distortion or deviation in the handling of children of delinquent actors outside conventional judicial channels as stated in Commentary Rule 11 UN Resolution 40/33, UN Standard Minimum Rule for the Administration of Juvenile Justice.

Diversion itself is aimed at:

1. Avoiding detention. With the existence of Diversion, it is hoped that children can avoid detention and the cases can be resolved without sacrificing the interests of the children.

2. Avoid being stamped / labeled or stigmatized, so that it does not affect the mental development of the child.

3. Improve life skills for actors, because Diversion provides opportunities for actors to be involved in the process.

4. Perpetrators can be held responsible for their actions.

5. Prevent the perpetrator from repeating the crime

6. Promote necessary interventions for victims and perpetrators without having to go through a formal process.

With the Diversi program, it will prevent children from the process of the justice system. Diversi will keep children away from the negative influences and implications of the judicial process. The implementation of diversion must involve the victim, the perpetrator, the family of the victim and the perpetrator, the community and parties with an interest in a criminal act that has occurred to reach an agreement and settlement. Restorative justice is considered a new way of thinking (paradigm) in looking at a crime committed by a child. The police as the vanguard in law enforcement have a large enough responsibility to synergize their duties and authorities Article 5 of the Law on Child Criminal Regulation (SPPA) states that the criminal justice system is obliged to prioritize a restorative justice approach, the Juvenile Criminal Justice System as referred to above includes investigations and child criminal prosecution carried out in accordance with statutory provisions.

During the Covid-19 pandemic, the Satreskrim Polres Labuhanbatu in handling children who commit criminal acts pays attention to children's rights, namely survival rights, development rights, protection rights, participation rights. The implementation of the health protocol in dealing with children who are in conflict with the law at the Labuhanbatu Police Criminal Unit is as follows:

1. Enter the examination room and wash your hands with soap.

2. Check body temperature before checking.

3. Wear a mask during the examination or if there is no PPA Polres unit, they will provide free masks.

4. Investigators or assistant investigators also use masks when examining.

5. The diversion room is always sprayed with disinfectant regularly and has a hand sanitizer and is air-conditioned.

6. In the case of a child who commits a criminal act with a penalty of over 5 years and can be detained. Children are ordered to report 2 (two) times a week and are guaranteed by the child's family.

\section{INHIBITING FACTORS IN INVESTIGATING CHILD- REN}

As for the inhibiting factors for the Labuhanbatu Police in investigating minors as criminals, including the following:

1. The absence of a special detention room for children 
The Labuhanbatu Police do not yet have a special detention room for children, so if for some reason it requires investigators to carry out detention such as cases with high threat such as murder it will be difficult to carry out or other cases when entrusted to parents or the guardian is very dangerous to the safety of the life of the child in question and there is no child penitentiary in Denpasar. For detentions that have been carried out by the Labuhanbatu Police, investigators have temporarily used the empty staff room. In cases involving children, if according to the results of the examination, the investigator is of the opinion that the child has not reached the age of 12 (twelve) years of committing or is suspected of committing a criminal act, it can still be fostered by the parents, guardian or foster parent, the investigator returns the child to the parent, guardian or foster parent, this has been justified in accordance with Article 21 of Law No. 11 of 2012 concerning the Juvenile Justice System.

2. There are no special officers for child investigators. For child investigators, the Labuhanbatu Police do not yet have investigators with special expertise as intended in Law No. 11 of 2012, concerning juvenile justice, and in the event of a criminal act involving children as the perpetrator, the general criminal investigator is still carrying out the investigation process but still adhering to the provisions stipulated in Law No. 11 of 2012 concerning Juvenile Justice. Then regarding the limited personnel, the Labuhanbatu Police only has one female police investigator and even then does not have the special expertise to carry out investigations of children. Get around in terms of limited personnel, especially investigators who have special expertise for child investigations,

\section{CONCLUSION}

Children who are in conflict with the law during the covid 19 pandemic in Indonesia are given rights outside of the usual or before the covid 19 pandemic. Children's rights that are given in general are still carried out such as the right to survival, the right to survival, the right to protection, the right to participate. While the rights of children given during the Covid-19 period are providing health rights and implementing health protocols. To reduce the risk of transmission of covid 19, children who are in conflict with the law will resolved through Diversion, namely the transfer of handling cases of children suspected of having committed criminal acts from a formal process with or without conditions. In providing the rights of children who are in conflict with Indonesian law, in general, they have not done their best. The shortcomings or obstacles in granting rights to children in conflict with the law such as the Labuhanbatu Police Resort in investigating minors as perpetrators of crimes, namely the absence of special detention rooms for children, and the absence of special child investigators.

\section{REFERENCES}

Abdussalam. 2007. Hukum Perlindungan Anak. Jakarta: Restu Agung.

Atmasasmita, Romli. 2009. Problem Kenakalan Anak-anak Remaja Cetakan Kedua. Bandung: Armico.

Beneitez. Maria José Bernuz, Dumortier. Els., 2018. Why Children Obey the Law: Rethinking Juvenile Justice and Children's Rights in Europe through Procedural Justice. Youth Justice, 18 (1): 34-51. https://doi.org/10.1177/1473225417741225

Dellyana, Shanty. 2012. Wanita dan Anak di MataHukum Yogyakarta: Liberty.

Farasonalia, R. 2021. Selama Pandemi Covid-19, Kasus Anak Berhadapan dengan Hukum di Jateng Meningkat 10 Persen. Sumber: https://regional.kompas.com/read/2021/01/04/ 22393921/selama-pandemi-covid-19-kasus-anakberhadapan-dengan-hukum-di-jateng?page=all.

Farid, Mohammad. 2016. Hak Anak yang Berkonflik dengan Hukum. Cetakan Kedua. Yogyakarta: Setara.

Indarsih, Y. 2020. Application of Diversion for Children in conflict with the Law: How is the Criminal Justice system. Journal of Law Science, 2(1, Januari): 1-8. Retrieved from https://iocscience.org/ejournal/index.php/JLS/article/view/127 5

Law of the Republic of Indonesia Number 23 of 2002 concerning Child Protection.

Law of the Republic of Indonesia Number 39 of 1999 concerning Human Rights.

Makogon, Boris V. et al. 2020. Law Enforcement as Discretion and Legal Process. International Journal of Criminology and Sociology. Volume 9: 1918-1921. https://doi.org/10.6000/1929-4409.2020.09.223

Meliala, A. Qirom Syamsudin dan E. Sumaryono. 2005. Kejahatan Anak Suatu Tinjauan dari Psikologi dan Hukum. Yogyakarta: Liberty.

Presidential Decree Republik of Indonesia No. 36 of 1990 concerning Ratification of the Convention On The Rights Of The Child (Convention on the Rights of the Child).

Sagala, E. 2018. Hak Anak Ditinjau Dari Hukum Dan Hak Asas Manusia. Jurnal IImiah Advokasi, 6 (1): 16-23. https://doi.org/10.36987/jiad.v6i1.259

Sharyn Graham Davies and Jazz Robson. 2016. Juvenile (In) justice: Children in Conflict with the Law in Indonesia. Asia-Pacific Journal on Human Rights and the Law, 17 (1) : 119-147. https://doi.org/10.1163/15718158-01701009

Wadong, Maulana Hasan. 2012. Pengantar Advokasi dan Hukum Perlindungan Anak. Jakarta: Grasindo. 
Widayanti, N., dan Anoraga, P. 2007. Perkembangan Kejahatan dan Masalahnya Ditinjau dari Segi Kriminologi dan Sosial. Jakarta: Pradnya Paramita.
Yusuf, Y. 2019. KPAl Catat 11.116 Anak Tersangkut Tindak Kriminalitas. Sumber: www.metro.sindonews.com/berita/ 1386477/170/kpai-catat-11116-anak-tersangkut-tindakkriminalitas.

https://doi.org/10.6000/1929-4409.2021.10.134

(C) 2021 Riduansyah et al.; Licensee Lifescience Global.

This is an open access article licensed under the terms of the Creative Commons Attribution Non-Commercial License (http://creativecommons.org/licenses/by-nc/3.0/) which permits unrestricted, non-commercial use, distribution and reproduction in any medium, provided the work is properly cited. 